\title{
Capacity Market Implementation in Poland: Analysis of a Survey on Consequences for the Electricity Market and for Energy Management
}

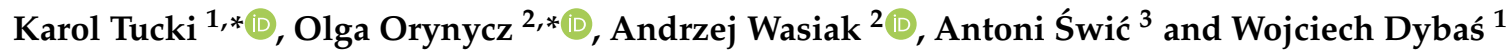 \\ 1 Department of Organization and Production Engineering, Warsaw University of Life Sciences, \\ Nowoursynowska Street 164, 02-787 Warsaw, Poland; wojciech.dybas@gmail.com \\ 2 Department of Production Management, Bialystok University of Technology, Wiejska Street 45A, \\ 15-351 Bialystok, Poland; a.wasiak@pb.edu.pl \\ 3 Faculty of Mechanical Engineering, Institute of Technological Information Systems, Lublin University of \\ Technology, Nadbystrzycka 38 D, 20-618 Lublin, Poland; a.swic@pollub.pl \\ * Correspondence: karol_tucki@sggw.pl (K.T.); o.orynycz@pb.edu.pl (O.O.)
}

Received: 9 February 2019; Accepted: 20 February 2019; Published: 4 March 2019

\begin{abstract}
The power sector is currently experiencing a dynamic transformation, resulting not only from EU directives, but also from current problems, mainly related to ensuring energy security for customers. For this reason, in Poland, it was decided that the model of electricity market operation needed to be changed. A dual market has been created, and a separated segment is the capacity market. This solution operates, in addition to other power mechanisms, in many European Union countries, e.g., in France, Great Britain, and Italy. The experience of these countries indicates the positive impact of the power market on various aspects of the power sector, such as legal, economic, technical and technological, social, and infrastructural aspects, mainly due to technological neutrality and open competition between power suppliers. The creation of the structure of an energy market drastically changes the rules of energy management, which requires investigations concerning the impact of those factors on the energy sector in Poland. The aim of this work is to examine the impact of the power market on the Polish power sector, and to determine the impact of individual consequences on several predefined areas. For this purpose, a questionnaire survey was used. The purpose of a detailed analysis is to develop probable scenarios for the sustainable development of the Polish energy sector.
\end{abstract}

Keywords: power market; energy market; power auction; energy policy; perspectives of development

\section{Introduction}

The structure of the Polish electricity mix results from the long-term development of coal energy $[1,2]$. The current situation in the international arena, including to a large extent EU regulations, has prompted the Polish government to reflect on the responsible transformation of the sector towards the diversification of primary energy sources [3], the reduction of $\mathrm{CO}_{2}$ emission in the manufacturing sector [4,5], and the increase in the share of energy produced by renewable sources [6-9]. Evidently, these aspects are in line with the principles of sustainable development policy [10].

The objectives of the climate and energy package include a $20 \%$ reduction in $\mathrm{CO}_{2}$ emissions as compared to 1990 levels, an increase in the share of renewable energy to $20 \%$ in total consumption [11], and an increase in energy efficiency, mainly due to the extensive thermo-modernization of buildings. The time horizon defined in the EU Directive is 2020 [12,13]. However, the plans of the European Commission for the next decade are already pointing to the definition of new, more rigorous goals as well as the gradual withdrawal from conventional energy in favor of renewable energy sources $[14,15]$. 
Those goals are consistent with the principles of sustainable development, in which not only technical factors but also economic and social factors, and the respect for the natural environment, have to be taken into account. Such a direction of aspirations requires sustainable resource management in the environmental dimension.

The key task, however, from the point of view of the national power management system, seems to be to ensure the country's energy security [16], which, in the face of uncontrolled expansion of RES and the priority of "green" technologies in access to the network, could be reduced $[17,18]$. For this reason, it became necessary to create such an environment for reforms in the sector, which would allow parallel growth of "green energy" and energy security and, consequently, fulfill the objectives of the climate and energy package $[19,20]$.

It was observed that energy security is based on several fundamental pillars [21,22]:

- Adequate quality of network infrastructure, whose development is determined by appropriate regulatory mechanisms;

- An appropriate amount of production capacity, developed through competition mechanisms, which significantly depends not only on the volume of installed capacity, but also on other factors such as availability, location, technology;

- Energy storage facilities, for which the point of development is the need to stabilize the network, for which increasing the share of unstable RES sources in the energy sector will also be an increasing challenge [23];

- Sector coupling, which can be an enabling solution for energy efficiency improvement [24].

The course of sustainable development processes must also take into account the interdependence and connections between various socio-economic areas.

Previous solutions for maintaining strategic reserves carried the risk of a sharp increase in the prices of electric energy as soon as shortages were recorded in own generation, and these solutions, according to the forecasts of Polskie Sieci Elektroenergetyczne (Polish Electroenergetic Grids), will occur around 2021-2023 depending on the adopted scenario of reaction to the EU BAT conclusions (Best Available Techniques-EU environmental guidelines included in the legislative package regarding various sectors of the economy) $[25,26]$.

Two models were developed:

- The so-called "Modernization" scenario, assuming a wide modernization of existing generation sources with a view to increasing the efficiency of production and reducing emissivity;

- The so-called "Withdrawals" scenario, assuming the obsolescence of generating sources that do not meet emission standards or production efficiency below a reasonable level.

The previously functioning single-market energy market did not provide sufficient investment signals for the modernization or construction of new generation sources [27,28].

Growing investment risk, long and uncertain periods of investment return as well as the unstable development of RES caused by additional, non-market support mechanisms led to changes in the current functioning of the energy market model, crucial from the point of view of energy security. A separate market segment was created-A power market $[29,30]$. The energy market has become a dual-product market, where, apart from the purchase and sale of physically consumed electricity, the readiness to supply it is also purchased [31,32].

Economic development is closely related to the condition of the power sector, which in turn depends to the greatest extent on the level of energy security and sustainable development policy $[33,34]$. Dynamic changes in the structure of the electricity mix are caused, inter alia, by changes in the development strategy of individual countries (of the so-called "Old Union"), which have the greatest impact on the creation of new legislative solutions [35], and are motivated by principles of sustainable development [36], and consequently climate policy [37], as an indispensable element of planning reforms in the power sector [38]. 
In the German energy system, we can currently observe a gradual phase-out of nuclear and coal-fired power for renewable energy sources for which good generation sites are far from the load centers $[39,40]$. Capacity mechanisms can help to safeguard the security of electricity supply, but they must be designed so as to avoid distortions of competition in energy markets. A lack of appropriate mechanisms and regulations in the long term may lead to an inevitable market zone split [41]. The experience of the German power market is therefore important for all EU countries.

Germany has been using various power mechanisms for many years, supporting the maintenance of reserves at a responsible level and balancing supply and demand in conditions of unstable expansion of renewable energy [42,43]. For this purpose, a strategic reserve and a network reserve [44] are maintained. They are intended to provide revenues to conventional power plants, ready to supply electricity during periods of shortages in RES generation, e.g., on windless or cloudy days [45]. The necessity of using support mechanisms for stable, conventional energy sources does not fit into the list of arguments supporting the thesis about the change of the energy market model based solely on renewable sources [46]. The discussion on this subject will take place until the capacity of industrial, large-scale storage of electricity is developed [47]. Summing up the brief characteristics of the German power industry, one can conclude that the galloping development of renewable energy, based on various energy sources, is supported by a significant volume of installed capacity in conventional, stable units [48,49]. In Germany, it was assumed that the electricity market should ensure security of supply and reduce costs in order to allow for innovative and sustainable development.

The largest volume of electricity generated in France is attributable to nuclear sources $(73 \%)$-stable and zero-emission [50,51]. It is also worth mentioning the renewable energy (responsible for $19 \%$ of electricity produced) [52]. Specific geographical conditions and water availability in France were and are a determinant of the development of sources using water bleed energy (pumped storage power plants and hydropower plants) as well as the energy of ocean waters (tidal power plants) [53]. All of these issues are directed towards the country's energy competitiveness, the security of supply, and sustainable development [54].

The specificity of the French energy market results from the successively implemented, long-term energy policy [55], initially supported by capacity mechanisms in the form of planned reserves, followed by the introduction of a decentralized capacity market [56].

In the French model, the end recipient is obliged to acquire a certain volume of power, somehow reserved in the national power system [57]. The amount of such an obligation is directly proportional to the amount of electricity consumed. The capacity certificates, sold by energy producers and sites that can decrease their power capacity on demand, can be exchanged by auctions and OTC (over the counter). One capacity certificate is equivalent to $0.1 \mathrm{MW}$. Thus, there is a dual market, the energy market and the power market, together shaping a responsible pricing policy while maintaining a high level of energy security [58].

The energy economy of Great Britain is based to a large extent on the use of natural gas for electricity generation (43\%) [59]. It is a technology resulting from the possibility of quick responses to changes in RES supply, and considered in the current discourse on climate and energy reform as bridging due to its low $\mathrm{CO}_{2}$ emission, the use of its own resources, and its production flexibility, which is important for energy security $[60,61]$. Creating a stable environment for the development of renewable energy sources in the United Kingdom has historically been based on maintaining a strategic reserve, i.e. an overvalued level of power available in the system, ensuring the energy security of the state [62]. A few years ago, it was decided that a centralized power market with one system operator as the buyer needed to be developed and implemented. The model consists in subsidizing production units that are maintained in readiness in the event of a period of danger. Therefore, auctions are organized where manufacturers offer the operator power obligations and thus a certain volume of power that they are able to deliver to the system as needed. Offers are ranked based on criteria of the price, emissivity, and availability of a given production technology. Auction winners conclude long-term contracts with the operator $[63,64]$. Demand reduction mechanisms have also begun to 
develop, as they are the most effective form of power delivery to the power system [65]. As a result, the measures taken by the UK Government have increased the level of energy security and climate change towards the path to a sustainable, low-carbon future. The capacity market is the UK government's primary policy for ensuring security of electricity supply. The biggest challenge for the security of supply in the GB market is now providing flexibility rather than reaching an overall level of capacity.

By implementing solutions tested in other power mechanisms of Western countries, and by comparing functional solutions with specific conditions of the national power sector, we obtained an image of production resources (Figure 1) [66,67]. A gap has been defined at the appropriate level of generation capacity at the level of at least $8.5 \mathrm{GW}$, which gave rise to considerations regarding the change in the electricity market model from the single market to the dual energy and power market.

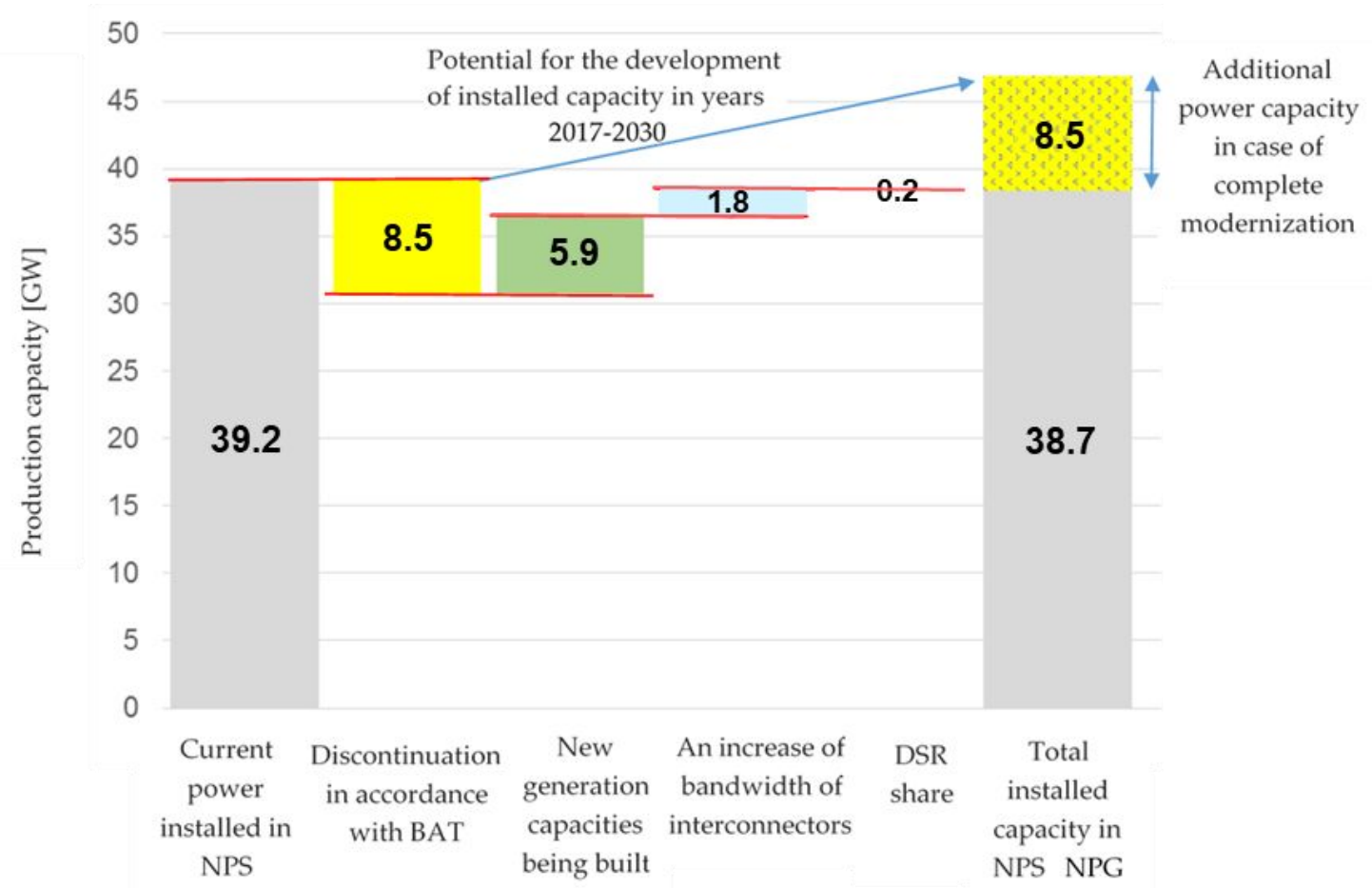

Figure 1. The perspective of changing the volume of installed capacity in the NES in the years 2020-2030 according to the Best Available Techniques (BAT) conclusions.

The aim of the present work was to analyze the effects of the introduction of the power market in Poland. The change in the model of the electricity market determines multi-faceted consequences for significant areas of the national economy. The estimation of the results of the introduced regulations and a detailed analysis of the impact of functional solutions was aimed at estimating the development direction of the Polish power sector over the next several decades respecting the principles of sustainable development $[68,69]$. The analysis also includes the DSR (demand side response) service for reducing power demand using power demand management tools. This factor contributes to strengthening the security of the NPG and balancing the system in critical situations.

\section{Methodology}

The power market in Poland is a new mechanism. For this reason, a study in the form of an expert survey was selected to analyze the potential effects of its introduction, which will provide knowledge about shaping appropriate mechanisms to disseminate the idea of sustainable development. The survey was completed by 30 experts holding managerial positions in the Poland capacity market. Two questionnaires were received with some questions unanswered, so they were not taken into account in the analysis. For this reason we have 28 columns in Figure 2. One column corresponds to one expert. 


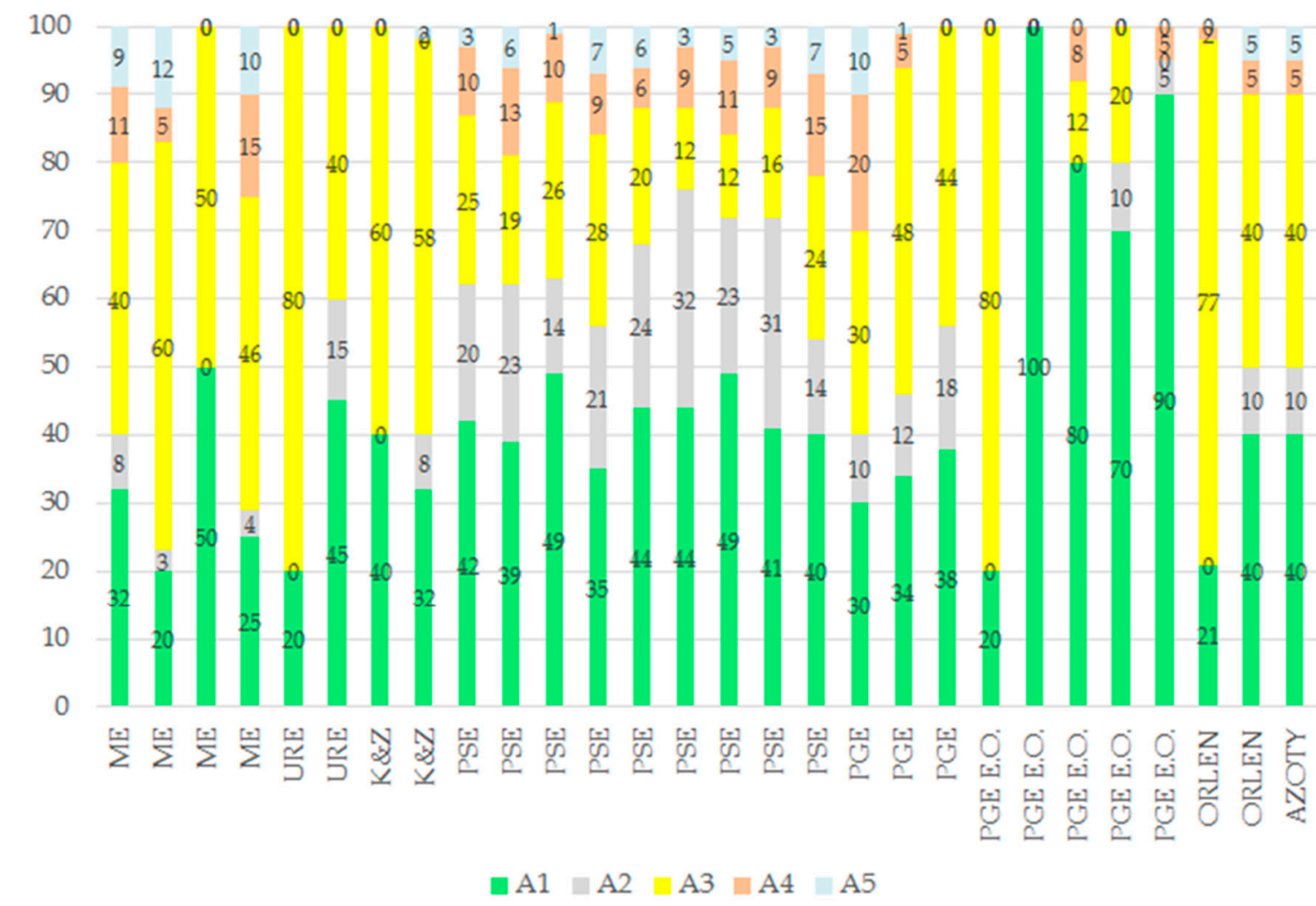

Figure 2. Survey results- the general section (impact of the power market on a given area of the electric energy sector).

The preparatory phase, constituting the substantive foundation of the questionnaire, is an open form, addressed to the representatives of the power system operator and law enforcement authorities regarding the capacity market. The form contains open questions regarding the anticipated effects of the introduction of the capacity market in Poland and the estimated share of individual technology groups in the first power auctions. The experts' answers formed the basis for preparing the questions closed in the survey. In the survey, the respondents estimated the probability of a given effect of a dual-purpose market on the power sector, broken down into economic, social, technical and technological, legal, and infrastructural areas. They also chose the most likely scenario for the development of the power sector in Poland, determined by the introduction of a dual market. The most probable results and the vision of changes in the power industry over the next 20 years were determined from analysis of the answers.

Among the experts participating in the study, representatives of entities from the regulatory sector can be distinguished (PSE = Polskie Sieci Elektroenergetyczne SA; ME = Ministry of Energy; $\mathrm{K} \& \mathrm{Z}=$ Chancellery of the Prime Minister; ERO = Energy Regulatory Office) as well as electricity generation (PGE = Polska Grupa Energetyczna SA; PGE EO = PGE Energia Odnawialna SA, Tauron Wytwarzanie SA) and customers-DSR (ORLEN-PKN = Orlen SA; AZOTY = Grupa Azoty SA) and final customers. Representatives of the said entities were asked to indicate the likely effects of the implemented regulations and to estimate the share of individual technological groups in the upcoming power auctions.

From the answers sent in the above, a questionnaire was created, consisting of three sections:

- General (the purpose of the questions contained in this section was to identify the area with the largest impact of the implemented regulations);

- Scenario (the purpose of the questions from this section was to develop the most likely scenario of the development of the Polish power industry, referring both to European regulations and domestic strategies redefined by the market power); 
- Area (the purpose of the questions contained in this part of the survey was to examine the probability of occurrence of particular legal, economic, economic, or social effects that could be taken into account when preparing a long-term perspective for the power sector).

\section{Results}

The research focused on ensuring sustainable development is presented in three sections: the general section, the scenario section, and the area section.

In the first section (general section), respondents were asked to qualify the impact of introducing the power market in Poland to particular areas of the power sector. For this purpose, $100 \%$ of the five predefined groups of regulation effects were separated (Figure 2).

The aim was to examine to what extent the introduction of the power market affects the legal, technical and technological, economic, social, and infrastructural areas, and hence in which areas the most noticeable effects of the introduced power mechanism will occur. The choices were as follows:

- The regulatory area (A1) covers all types of legal acts, both national and European, influencing the shaping of the electricity market, as well as implementing acts and European Commission regulations regarding state aid.

- Technique and technology (A2) covers all electricity generation technologies, including increases in the efficiency of production and techniques that reduce the level of demand for electric energy (DSR with internal generation and without generation) as well as changes in demand in the daily cycle (e.g., energy storage).

- The economy (A3) covers the broadly defined financial liquidity of energy enterprises as well as the profitability of investments in modernization or the construction of new generation sources.

- The social area (A4) covers all final consumers (individual and industrial). Power security, which is key for the power market, is mainly addressed in this area. Society acts as the final payer for readiness and the most important beneficiary.

- The infrastructure area (A5) covers all kinds of activities related to network infrastructure-the construction or reconstruction of overhead or cable lines and additional infrastructure (e.g., switching stations).

There is a noticeable difference in the prediction of the impact of regulation on individual areas depending on the subject being surveyed. The values averaged for each subject are shown in Figure 3 .

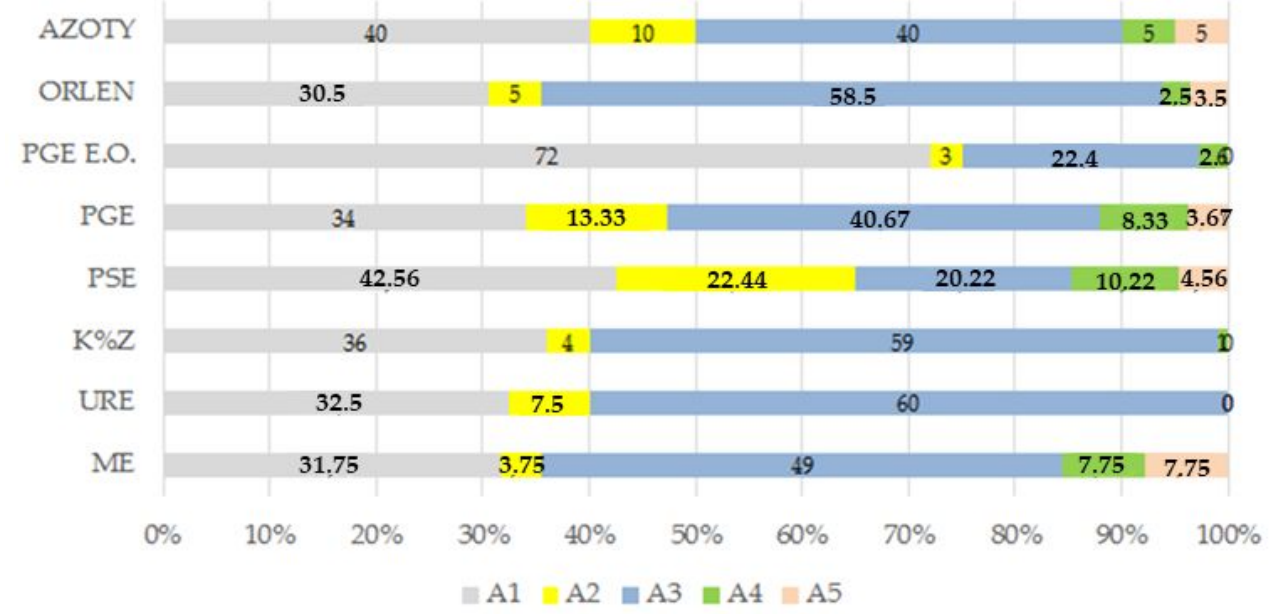

Figure 3. Percent load distribution of regulation effects.

All surveyed entities point to a significant impact of the introduced regulations on the legal (A1) and economic (A3) areas. It can be concluded that the power market in Poland will be a strong 
incentive to change the model of functioning of these areas in the current shape. The direction of changes is difficult to estimate at this time. A marginal impact on the infrastructure area is forecasted (A5), which is due to the relatively small necessity to modernize power grids as a result of changes taking place in the manufacturing sector.

Entities focused on the creation of regulations (ME, ERO, and $\mathrm{K} \& \mathrm{Z}$ ) indicated significant changes in the existing functioning of the legal area of the power sector. This is connected with a profound change in the existing single-commodity market, where the only commodity was electricity. The expected effects of the introduction of the capacity market in Poland are reflected in the creation of a separate market segment- the capacity market, operating in parallel to the current one. The dual market, however, introduces the need to regulate the participation of two seemingly independent transaction areas.

The entity responsible for all power market processes (in the PSE study), also performing an operational role, draws attention to the effects visible in the area of technique and technology. There is a connection in the smart metering of a network between the generating unit and the operator, which is a requirement for regular trading in the power market. The development of smart metering is a side effect of participation in the power market. In the operator's opinion, the area of technology and technology is also important due to the forecasted share of the demand side in the capacity market and the development of electricity storage technologies in the medium-term perspective by entities representing renewable energy sources. Increasing the controllability of renewable sources, such as wind farms or solar farms, allows for a greater share of the above-mentioned units in power auctions in future years.

Recipients of regulations (PGE, PGE EO, ORLEN, and AZOTY) pay attention to the crucial importance of an appropriate legal framework for process correctness, interest in providing DSR services, or power market participation by entities using the RES support system-participation in the power market necessarily involves a decline in the support obtained from the RES auction for remuneration for readiness on the power market.

The introduction of a dual-market model in Poland prompts us to consider the shape of the national power industry in the future. Poland faces very serious decisions regarding a long-term energy strategy, a future electricity mix that coincides with global trends, such as fuel diversification and the annual increase in the share of "green" energy.

The aim of the scenario section (second section) was to investigate in which direction the Polish energy industry is heading and how the introduction of the power market will affect the strategy chosen so far.

The first part is the estimation of the share of individual energy technologies in the capacity market. The results show a graph of the percentage share of individual technologies in the upcoming power auctions (Figure 4). Respondents pointed to the decisive advantage of the number of coal-fired power plants participating in the auctions. The forecasted significant share of gas power plants or the demand side (DSR) is noteworthy. This demonstrates the potential visible increase in public awareness of managing current energy consumption and modeling own needs dictated by the demand of the network. 


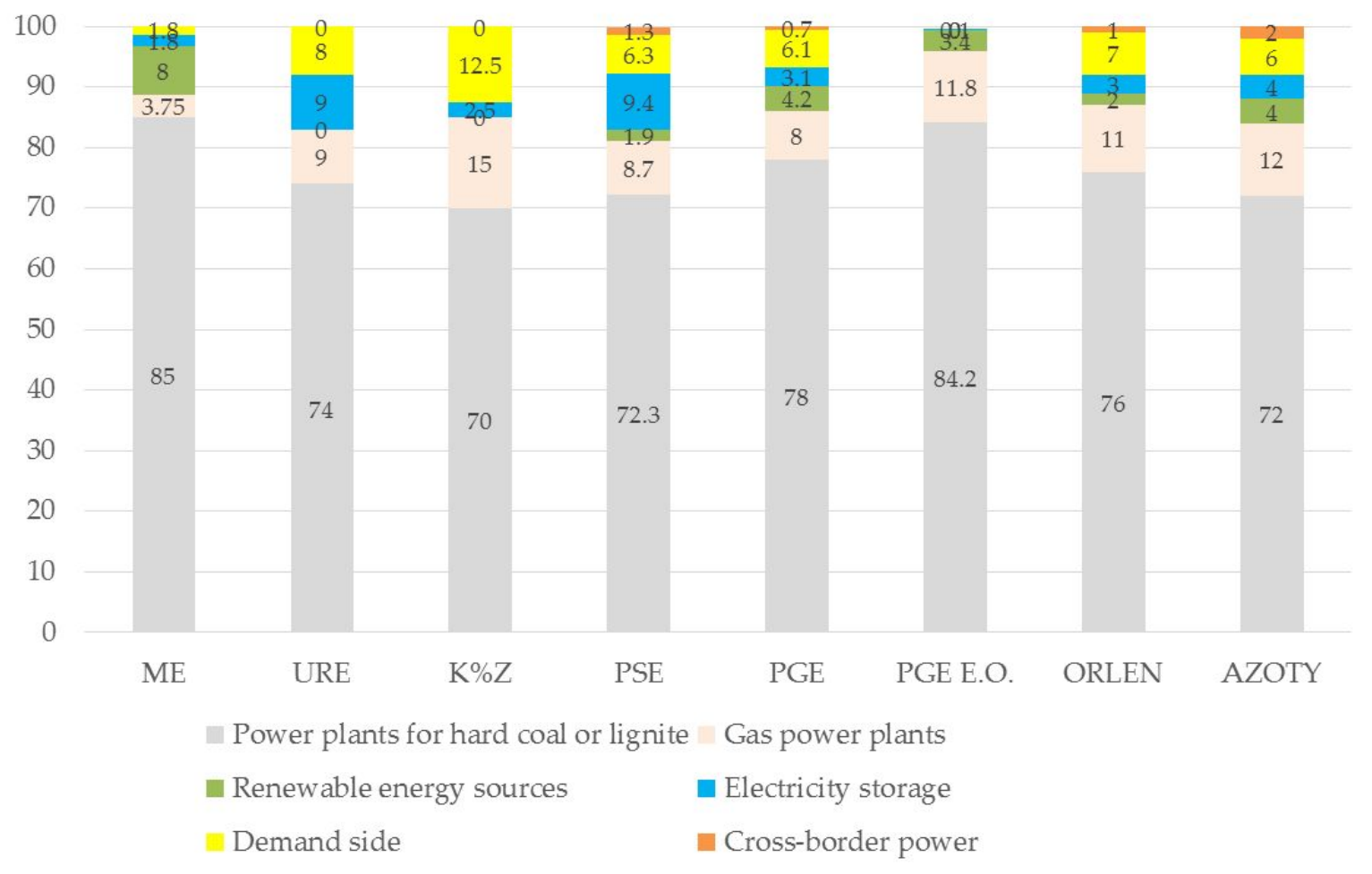

Figure 4. Percentage share of generation/reduction technology in the capacity market.

By averaging the results of the survey, a probable distribution of the technologies involved in the auction was obtained (Figure 5).

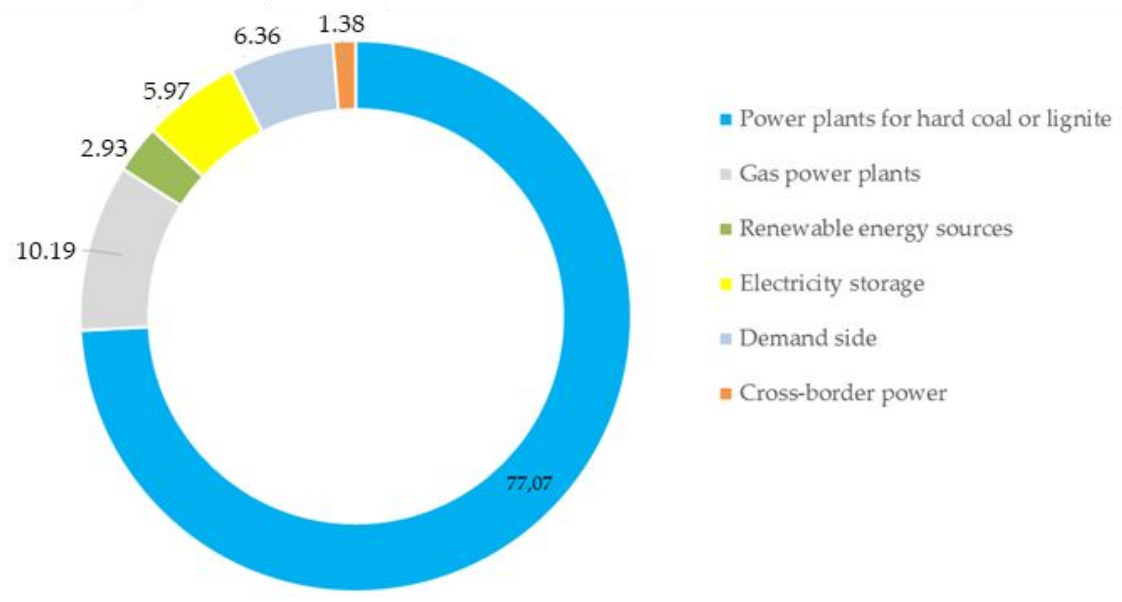

Figure 5. Potential technological mix during the next power auction.

In the second part of this section, the respondents determined the probability of occurrence of predefined scenarios for the Polish power industry. Among them were

- A conservative scenario covering the modernization and construction of new conventional sources, with small fluctuations in the volume of installed capacity in RES sources;

- An innovative scenario including increased interest in providing demand reduction services, construction of energy storage, and growing imports of electricity;

- An EU scenario covering the dynamic development of renewable energy and stable gas sources, mainly for the needs of the balancing market; 
- A nuclear scenario, replacing coal-fired generating units with the construction of a nuclear power plant with a capacity corresponding to discontinued sources.

The long-term perspective is shown in Figure 6. After analyzing the results of the expert study, the average probability distribution of one of the four scenarios was estimated.

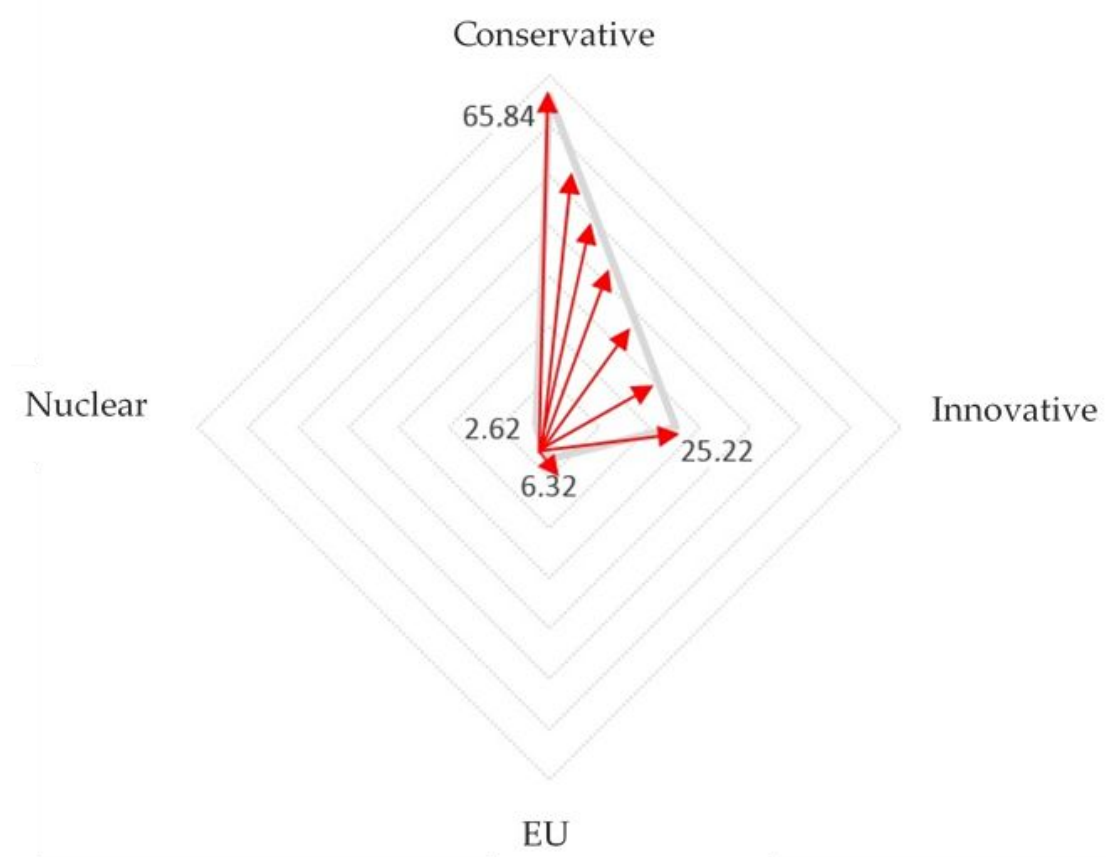

Figure 6. Directions of development of the national power sector according to the results of the survey.

There is a clear advantage in the conservative scenario. In the perspective of several decades, it is predicted that the existing trends in the dominance of conventional energy in the domestic structure of generation sources will be maintained (65.84\%). However, it should be assumed that the conventional background of the power sector will be a favorable environment for the sustainable development of innovation in the power industry, such as new methods of electricity storage and smart meters for monitoring the supply and demand situation on the market in the current mode (25.22\%). In spite of the few responses to the EU scenario, the opinions of experts on the development of green energy, as an inevitable consequence of the introduced changes, can be interpreted as a path for the Polish energy sector. The main obstacle is their lack of futility. If the consequence of introducing the power market in Poland will be the market model described herein, as predicted in the results of this study, the possibilities of the current control of production sources and buffering of electricity in warehouses will allow for the development of renewable energy sources, even though the answers of experts do not directly indicate the above sources as beneficiaries of the capacity market.

The purpose of the research area section (Section 3) was to define the detailed effects that result from the introduction of these regulations in each of the sector areas studied (Table 1). To this end, the weighted average was used, and the following criteria for the division of effects were adopted:

- $0 \%$ : no influence;

- $1-10 \%$ : insignificant effect;

- 11-20\%: low impact;

- $21-30 \%$ : noticeable impact;

- 31-50\%: significant impact;

- $\quad 51-100 \%$ : critical impact.

Each category was assigned a numerical category (from 0 -no impact, to 5-critical impact). By means of the arithmetic mean method, weights for individual effects were then calculated. 
Table 1. Symbols used in the tests.

\begin{tabular}{cl}
\hline A1 & Regulatory area \\
\hline P1 & Improvement of regulatory stability of the power sector \\
P2 & New contracts for supplying power from abroad \\
P3 & Distortion of competition between manufacturing technologies \\
P4 & Increased competition between renewable energy and conventional energy \\
\hline A2 & Technique and technology area \\
\hline T1 & Construction of new conventional sources \\
T2 & Development of electricity storage technologies \\
T3 & Modernization of existing conventional sources \\
T4 & Reduction of CO 2 emissions and increase of production efficiency \\
T5 & DSR development \\
T6 & Construction of new renewable energy sources \\
\hline A3 & Economy area \\
\hline E1 & Improving the profitability of conventional power plants operation \\
E2 & Increase in revenues of entrepreneurs participating in DSR \\
E3 & Significant increase in electricity prices for households \\
E4 & Significant increase in electricity prices for businesses \\
\hline A4 & Social area \\
\hline S1 & Improvement of energy security of customers \\
S2 & Increase in dissatisfaction with the power charge \\
S3 & DSR development \\
S4 & Improvement of sentiment in mining \\
\hline A5 & Infrastructure area \\
\hline I1 & Development and modernization of power grids \\
I2 & Development of cross-border connections \\
I3 & Smart metering of networks \\
I4 & Development of distributed generation \\
\hline &
\end{tabular}

The arithmetic weight of the effects of regulation is presented in Table 2.

Table 2. The arithmetic weight of the effects of regulation.

\begin{tabular}{cccccccccc}
\hline Effect & $\begin{array}{c}\text { Arithmetic } \\
\text { Weight }\end{array}$ & Effect & $\begin{array}{c}\text { Arithmetic } \\
\text { Weight }\end{array}$ & Effect & $\begin{array}{c}\text { Arithmetic } \\
\text { Weight }\end{array}$ & Effect & $\begin{array}{c}\text { Arithmetic } \\
\text { Weight }\end{array}$ & Effect & $\begin{array}{c}\text { Arithmetic } \\
\text { Weight }\end{array}$ \\
\hline P1 & 4.8 & T1 & 2.9 & E1 & 4.8 & S1 & 4.8 & I1 & 3.1 \\
P2 & 1.3 & T2 & 2.0 & E2 & 2.8 & S2 & 1.9 & I2 & 2.6 \\
P3 & 1.5 & T3 & 4.1 & E3 & 1.0 & S3 & 2.2 & I3 & 4.3 \\
P4 & 1.5 & P4 & 1.2 & E4 & 1.3 & S4 & 0.6 & I4 & 0.6 \\
& & T5 & 1.4 & & & & & & \\
\hline
\end{tabular}

Respondents' answers, along with the qualification of the impact of a given effect on the power sector, are presented in Figure 7. A detailed analysis was made of the effects of introducing a power market, the impact of which on the power sector exceeds $20 \%$. Eight effects have been defined with noticeable, significant, or critical impact on the shape of the power sector. These are as follows: I3: 46.93\%; I1: 31.85\%; S1: 66.14\%; E2: 26.65\%; E1: 62.36\%; T3: 41.11\%; T1: 27.08\%; P1: 69.93\%. 


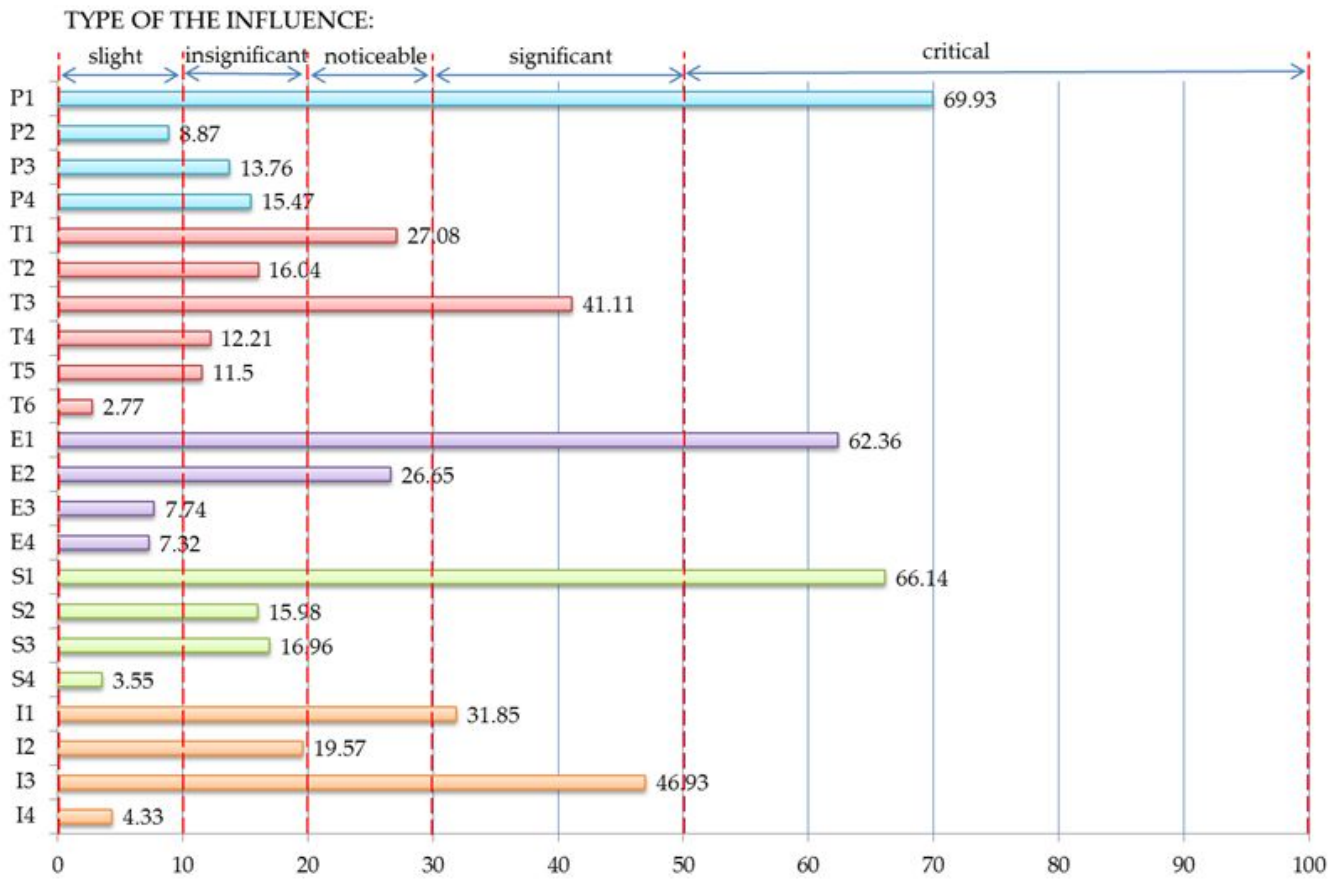

Figure 7. Categorization of the impact of the power market introduction on the energy sector.

Giving weights to the individual effects allowed for estimation of the volume-weighted average probability of the load of individual sectors, which is shown in Figure 8.

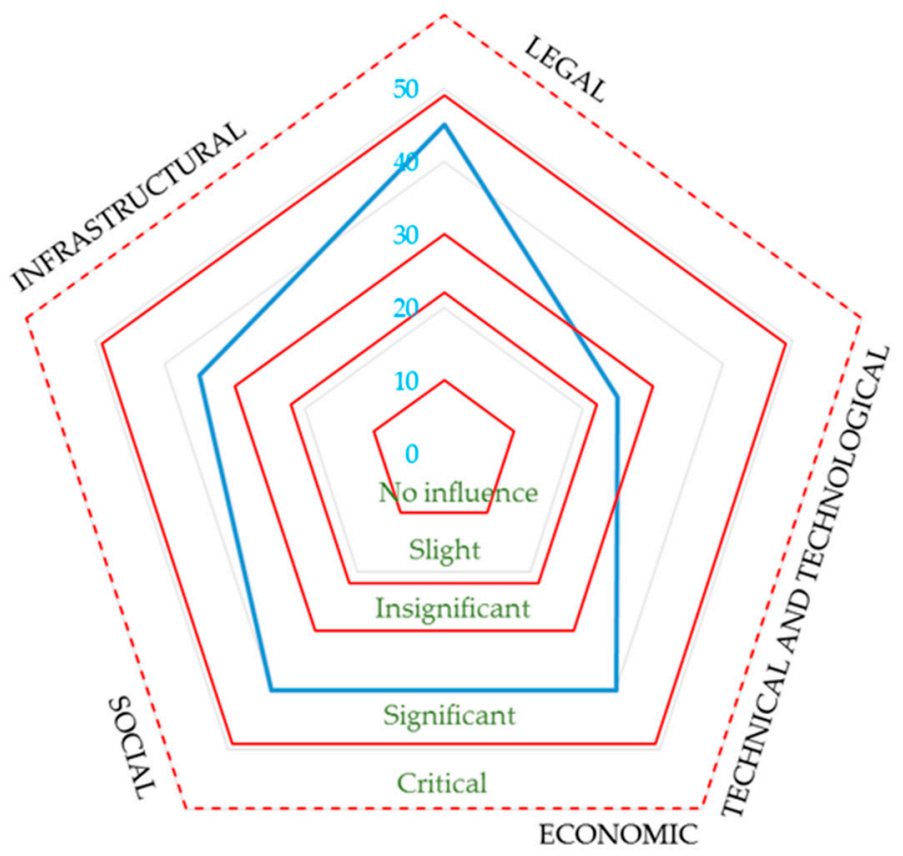

Figure 8. Plot of the effects of regulation effects.

The power market in Poland seems to be receiving positive feedback from the industry. It can be a solution to many problems in the power sector, concerning not only the supply side but also the recipients. Among the most probable effects of the introduction of the discussed regulations, there was an improvement in the energy security of the recipients, which is consistent with the legislator's intention and allows one to look optimistically at the potential imbalance of the system in the coming years. Much attention has been paid to improving the financial condition of producers and thus to 
increasing the stability of the operation of the power plant. Thus, in the future, the conditions created to support basic sources will be the driving force for the development of uncontrolled, renewable energy sources. Expenses incurred to support sources participating in the capacity market, according to respondents, will satisfy the needs of modernization of existing units, and to a much lesser extent will allow one to think about future multi-million investments. As a side effect of participation in the power market, the promotion of smart metering will become popular. It can be stated that respondents' opinions on potential effects are convergent with the needs that a Power Market Act would satisfy.

\section{Conclusions}

The results of an expert study conducted to identify the potential consequences of the introduction of the capacity market in Poland and the long-term effects of regulatory impact on the energy sector are not surprising. The opinion of experts on the future of domestic energy and changes determined by the capacity market is consistent with the legislator's intentions. The mechanism was introduced responsibly and will meet needs, and it can become a valuable tool for the implementation of the goals of sustainable development.

On the basis of the dual market, a new approach to energy management can be built in general, as the revolution currently taking place in all areas of the sector has been based on a solid base of fundamental rights, namely energy security and sustainable development. Experts do not predict a sharp change in electricity generation. The results of the study, although they do not directly point to a change in direction only towards RES, coincide with trends currently observed in Europe and worldwide - the development of renewable energy, reductions in emissions due to energy production, and a rational look at energy as a product according to the principles of sustainable development. The analysis allows one to draw the following conclusions:

- There are a number of mechanisms to maintain energy security. Taking into account the specific conditions of the Polish power sector, the choice of a centralized power market seems to be the right choice, as it allows for a rational, competitive participation of all electricity generation technologies and DSR entities in the power auction. Rationalization manifests itself primarily through the conduct of the auction in the Dutch formula, with a declining price.

- The developed model of the Polish power market admits entities from the manufacturing sector and recipients to the auction, taking into account the actual restrictions. The inclusion of these aspects is manifested through the introduction of a correction coefficient of availability (KWD) for each technology.

- In each of the areas of the power sector predefined in the study, experts point to the effect of introducing a power market that strongly affects the direction of future changes. It is worth noting that the level of energy security and the construction and modernization of conventional generation sources deserve special attention. Both factors, according to the survey results, are characterized by a high probability of occurrence.

- The capacity market allows for the creation of a strong foundation for the development of renewable energy sources, despite the fact that the new regulations will not support these technologies.

- The share in the power market somehow forces innovations in the energy sector. The development of smart metering or energy storage technology is included in the requirements for power suppliers.

- There is no forecast of a rapid technological change in the manufacturing sector. Economic signals for investments in the generation sector will go mainly to conventional power plants, to gas-fired power plants, and to the demand side and result in their modernization. The role of DSR on the electricity market will increase significantly. 
- The capacity market will be a kind of guarantee for the return on investments incurred. Experts point to making decisions on the construction of an offshore wind farm or a nuclear power plant motivated by a new remuneration mechanism for readiness.

- The modern electricity grids worldwide have begun to rely more heavily on renewable energy sources, most of which are intermittent and distributed in nature. There is a concern that grid operators and power markets will struggle to cope. The subject of intense interest to power generation companies and transmission organizations across the globe are experiences from the German power market in this regard.

- It is estimated that in the near future we will observe in the EU a transition, for example, in gas engines, from an electricity market to one that is predominantly supplied by intermittent renewables balanced with flexible generation.

- In the largest EU countries, Demand Response (DR) is being prioritized in managing electricity networks, particularly in case of shortage risks in national energy systems [70].

- The introduction of a power market should affect the principles of energy management, opening more space for renewable energy sources and supporting energy efficiency on the side of consumers, contributing therefore to an increase of sustainability in the economy.

- It can be assumed that the marked change being introduced will also create an increase in energy security and bring Polish energy to a state closer to that of Germany.

Author Contributions: Conceptualization, K.T. and W.D.; methodology, O.O. and A.W.; validation, A.Ś. and K.T.; Investigation, O.O. and A.W.; writing—original draft preparation, A.S and W.D.; funding acquisition, A.Ś.

Funding: The authors wish to express gratitude to Lublin University of Technology for financial support given to the present publication (Antoni Świć). The research was carried out under financial support obtained from the research subsidy of the Faculty of Engineering Management (WIZ) of Bialystok University of Technology (Olga Orynycz, Andrzej Wasiak).

Conflicts of Interest: The authors declare no conflict of interest. The funders had no role in the design of the study; in the collection, analyses, or interpretation of data; in the writing of the manuscript; or in the decision to publish the results.

\section{References}

1. Kuchler, M.; Bridge, G. Down the black hole: Sustaining national socio-technical imaginaries of coal in Poland. Energy Res. Soc. Sci. 2018, 41, 136-147. [CrossRef]

2. Manowska, A.; Tobór-Osadnik, K.; Wyganowska, M. Economic and social aspects of restructuring Polish coal mining: Focusing on Poland and the EU. Resour. Policy 2017, 52, 192-200. [CrossRef]

3. Gnatowska, R.; Moryń-Kucharczyk, E. Current status of wind energy policy in Poland. Renew. Energy 2019, 135, 232-237. [CrossRef]

4. Wierzbowski, M.; Filipiak, I.; Lyzwa, W. Polish energy policy 2050-An instrument to develop a diversified and sustainable electricity generation mix in coal-based energy system. Renew. Sustain. Energy Rev. 2017, 74, 51-70. [CrossRef]

5. Gawlik, L.; Szurlej, A.; Wyrwa, A. The impact of the long-term EU target for renewables on the structure of electricity production in Poland. Energy 2015, 92, 172-178. [CrossRef]

6. Wang, X.; Nathwani, J.; Wu, C. Visualization of International Energy Policy Research. Energies 2016, 9, 72. [CrossRef]

7. Paska, J.; Sałek, M.; Surma, T. Current status and perspectives of renewable energy sources in Poland. Renew. Sustain. Energy Rev. 2009, 13, 142-154. [CrossRef]

8. Paska, J.; Surma, T. Electricity generation from renewable energy sources in Poland. Renewa. Energy 2014, 71, 286-294. [CrossRef]

9. Oniszk-Popławska, A.; Rogulska, M.; Wiśniewski, G. Renewable-energy developments in Poland to 2020. Appl. Energy 2003, 76, 101-110. [CrossRef] 
10. Jurasz, J.; Dąbek, P.B.; Kaźmierczak, B.; Kies, A.; Wdowikowski, M. Large scale complementary solar and wind energy sources coupled with pumped-storage hydroelectricity for Lower Silesia (Poland). Energy 2018, 161, 183-192. [CrossRef]

11. Bel, G.; Joseph, S. Climate change mitigation and the role of technological change: Impact on selected headline targets of Europe's 2020 climate and energy package. Renew. Sustain. Energy Rev. 2018, 82, 3798-3807. [CrossRef]

12. Liobikienè, G.; Butkus, M. The European Union possibilities to achieve targets of Europe 2020 and Paris agreement climate policy. Renew. Energy 2017, 106, 298-309. [CrossRef]

13. García-Álvarez, M.T.; Moreno, B. Environmental performance assessment in the EU: A challenge for the sustainability. J. Clean. Prod. 2018, 205, 266-280. [CrossRef]

14. Capros, C.; Kannavou, M.; Evangelopoulou, S.; Petropoulos, A.; Siskos, P.; Tasios, N.; Zazias, G.; DeVita, A. Outlook of the EU energy system up to 2050: The case of scenarios prepared for European Commission's "clean energy for all Europeans" package using the PRIMES model. Energy Strategy Rev. 2018, 22, $255-263$. [CrossRef]

15. Tulus, V.; Abokersh, M.H.; Cabeza, L.F.; Vallès, M.; Jiménez, L.; Boer, D. Economic and environmental potential for solar assisted central heating plants in the EU residential sector: Contribution to the 2030 climate and energy EU agenda. Appl. Energy 2019, 236, 318-339. [CrossRef]

16. Baltic Energy for Poland 2025. Baltic Energy Industry Forum 2018. Available online: https://www.beif.pl/ wp-content/uploads/2018/03/BEIF2018-5_questions_for_a_good_start-1.pdf (accessed on 2 February 2019).

17. Przygrodzki, M.; Gwóźdź, R. Model analysis of transmission constraints in Polish Power System. Przeglą Elektrotechniczny 2017, 93, 52-55.

18. Jaskólski, M. Modelling long-term technological transition of Polish power system using MARKAL: Emission trade impact. Energy Policy 2016, 97, 365-377. [CrossRef]

19. Adamczyk, J.; Dzikuć, M. The analysis of suppositions included in the Polish Energetic Policy using the LCA technique-Poland case study. Renew. Sustain. Energy Rev. 2014, 39, 42-50. [CrossRef]

20. Prognosis of Peak Demand for 2016-2035. (In Polish)Available online: http://gramwzielone.pl/uploads / files/Prognoza_pokrycia_zapotrzebowania_szczytowego_na_moc_w_latach_2016-2035.pdf (accessed on 2 February 2019).

21. Adamkiewicz, J. Conception of sustainable energy safety in a nutshell. Organ. Manag. Q. 2017, 104, $103-114$.

22. European Electricity Market-Diagnosis 2018. Available online: https://www.pse.pl/web/pse-eng/-/thediagnosis-of-the-european-electricity-market-from-the-point-of-view-of-the-polish-transmission-systemoperator (accessed on 2 February 2019).

23. Steinke, F.; Wolfrum, F.; Hoffmann, C. Grid vs. storage in a 100\% renewable Europe. Renew. Energy 2013, 50, 826-832. [CrossRef]

24. Brown, T.; Schlachtberger, D.; Kies, A.; Schramm, S.; Greiner, M. Synergies of sector coupling and transmission reinforcement in a cost-optimised, highly renewable European energy system. Energy 2018, 160, 720-739. [CrossRef]

25. Pinasseau, A.; Zerger, B.; Roth, J.; Canova, M.; Roudier, S. Best Available Techniques (Bat) Reference Document for Waste Treatment; European Commission Industrial Emissions Directive 2010/75/EU; Publications Office of the European Union: Luxembourg, 2018; pp. 1-851.

26. Badyda, K.; Niewiński, G.G.; Patrycy, A.; Orzeszek, W. Attempt to Estimate the Costs of Implementing BAT Conclusions for Large Combustion Plants. Soc. Inequal. Econ. Growth 2016, 46, 315-333.

27. Bayer, E.; Rączka, J.; Baker, P. Elements of Market Design for Poland. Available online: https://www. raponline.org/wp-content/uploads/2016/05/fae-elementsmarketdesignpoland-2015-oct.pdf (accessed on 2 February 2019).

28. Electricity and Gas Market in Poland-Status on 31 March 2017 TOE Report. Available online: http: / / www.toe.pl/pl/wybrane-dokumenty/rok-2017 (accessed on 2 February 2019).

29. State aid No. SA.46100 (2017/N)-Poland-Planned Polish Capacity Mechanism. Available online: http:/ / ec.europa.eu/competition/elojade/isef/case_details.cfm?proc_code=3_SA_46100 (accessed on 2 February 2019).

30. Commission Regulation (EU) 2017/2195 of 23 November 2017 Establishing a Guideline on Electricity Balancing. Available online: https:/ / eur-lex.europa.eu/eli/reg/2017/2195/oj (accessed on 2 February 2019). 
31. Capacity Market as Means to Avoid Blackouts. Assessment of the Impact of Implementation of a Comprehensive Capacity Market Mechanism in Poland. Available online: https://www.pkee.pl/file/ repository/Capacity_Market_PEA_Report_min.pdf (accessed on 2 February 2019).

32. Report on the Polish Power System Vision 2.0 Century Profile. Available online: https: / / www.agora-energiewende.de/fileadmin2/Projekte/2018/CP-Polen/Agora-Energiewende_report_on_ the_Polish_power_system_WEB.pdf (accessed on 2 February 2019).

33. Baltic Energy Technology Scenarios 2018. Available online: http://norden.diva-portal.org/smash/get/ diva2:1195548/FULLTEXT01.pdf (accessed on 2 February 2019).

34. Gawłowski, S.; Listowska-Gawłowska, R.; Piecuch, T. Conditions and forecast of Poland's energy safety for the period 2010-2110. Rocznik Ochrona Środowiska 2010, 12, 127-176.

35. Dusonchet, L.; Favuzza, S.; Massaro, F.; Telaretti, E.; Zizzo, G. Technological and legislative status point of stationary energy storages in the EU. Renew. Sustain. Energy Rev. 2019, 101, 158-167. [CrossRef]

36. Schirone, L.; Pellitteri, F. Energy Policies and Sustainable Management of Energy Sources. Sustainability 2017, 9, 2321. [CrossRef]

37. Brodny, J.; Tutak, M. Analysis of the diversity in emissions of selected gaseous and particulate pollutants in the European Union countries. J. Environ. Manag. 2019, 231, 582-595. [CrossRef] [PubMed]

38. The Model of the Optimal Energy Mix for Poland by 2060. Chancellery of the Prime Minister. Available online: https:/ / www.premier.gov.pl/en/news/news/the-model-of-an-optimal-energy-mix-for-polandby-2060.html (accessed on 2 February 2019).

39. Renn, O.; Marshall, J.P. Coal, nuclear and renewable energy policies in Germany: From the 1950s to the "Energiewende". Energy Policy 2016, 99, 224-232. [CrossRef]

40. Kies, A.; Schyska, B.U.; Bremen, L. Curtailment in a highly renewable power system and its effect on capacity factors. Energies 2016, 9, 510. [CrossRef]

41. Egerer, J.; Weibezahn, J.; Hermann, H. Two price zones for the German electricity market-Market implications and distributional effects. Energy Econ. 2016, 59, 365-381. [CrossRef]

42. Gugler, K.; Haxhimusa, A. Market integration and technology mix: Evidence from the German and French electricity markets. Energy Policy 2019, 126, 30-46. [CrossRef]

43. Ocker, F.; Ehrhart, K.M. The "German Paradox" in the balancing power markets. Renew. Sustain. Energy Rev. 2017, 67, 892-898. [CrossRef]

44. Neuhoff, K.; Diekmann, J.; Kunz, F.; Rüster, S.; Schwenen, S. A coordinated strategic reserve to safeguard the European energy transition. Utilities Policy 2016, 41, 252-263. [CrossRef]

45. Keles, D.; Bublitz, A.; Zimmermann, F.; Genoese, M.; Fichtner, W. Analysis of design options for the electricity market: The German case. Appl. Energy 2016, 183, 884-901. [CrossRef]

46. Renz, L.; Hartel, R.; Keles, D.; Fichtner, W.; Keko, H. Europe's Energy Transition-Insights for Policy Making, 1st ed.; Academic Press: London, UK, 2017; pp. 131-139.

47. Babrowski, S.; Jochem, P.; Fichtner, W. Electricity storage systems in the future German energy sector: An optimization of the German electricity generation system until 2040 considering grid restrictions. Comput. Oper. Res. 2016, 66, 228-240. [CrossRef]

48. Steinbacher, K.; Röhrkasten, S. An outlook on Germany's international energy transition policy in the years to come: Solid foundations and new challenges. Energy Res. Soc. Sci. 2019, 49, 204-208. [CrossRef]

49. Bergler, J.; Heim, S.; Hüschelrath, K. Strategic capacity withholding through failures in the German-Austrian electricity market. Energy Policy 2017, 102, 210-221. [CrossRef]

50. Kulczyński, D.W. Canadian Nuclear Power Plant refurbishment. Postępy Techniki Jądrowej 2015, 4, 33-37.

51. Annual Electricity Report 2015. Réseau de transport d'électricité (RTE). Available online: http:/ / www.rtefrance.com/sites/default/files/2015_annual_electricity_report.pdf (accessed on 2 February 2019).

52. Schumacher, K.; Krones, F.; McKenna, R.; Schultmann, F. Public acceptance of renewable energies and energy autonomy: A comparative study in the French, German and Swiss Upper Rhine region. Energy Policy 2019, 126, 315-332. [CrossRef]

53. Manzano-Agugliaro, F.M.; Taher, M.; Zapata-Sierra, A.; Juaidi, A.; Montoya, F.G. An overview of research and energy evolution for small hydropower in Europe. Renew. Sustain. Energy Rev. 2017, 75, 476-489. [CrossRef] 
54. Herder, M.D.; Kolström, M.; Lindner, M.; Suominen, T.; Tuomasjukka, D.; Pekkanen, M. Sustainability Impact Assessment on the Production and Use of Different Wood and Fossil Fuels Employed for Energy Production in North Karelia, Finland. Energies 2012, 5, 4870-4891. [CrossRef]

55. Beylot, A.; Guyonnet, D.; Muller, S.; Vaxelaire, S.; Villeneuve, J. Mineral raw material requirements and associated climate-change impacts of the French energy transition by 2050. J. Clean. Prod. 2019, 208, 1198-1205. [CrossRef]

56. European Commission. Commission Decision of 8.11.2016 on State aid Scheme. Available online: http:/ / ec. europa.eu/competition/state_aid/cases/261326/261326_1873332_314_5.pdf (accessed on 2 February 2019).

57. Impact Assessment of the French Capacity Market. A Contribution to the European Debate for a Secure Supply of Electricity. Available online: https://clients.rte-france.com/htm/an/mediatheque/ telecharge/20180901_RTE_Capacity_Market_Impact_Assessment_Executive_summary.pdf (accessed on 2 February 2019).

58. Report July 2018. Electricity and Gas Interconnections in France. Available online: https://www.cre.fr/ content/download/19500/234750 (accessed on 2 February 2019).

59. Energy consumption in the UK July 2018. Available online: https://assets.publishing.service.gov.uk/ government/uploads/system/uploads/attachment_data/file/729317/Energy_Consumption_in_the_ UK_ECUK_2018.pdf (accessed on 2 February 2019).

60. Hardt, L.; Owen, A.; Brockway, P.; Heun, M.K.; Barrett, J.; Taylor, G.P.; Foxon, T.J. Untangling the drivers of energy reduction in the UK productive sectors: Efficiency or offshoring? Appl. Energy 2018, 223, 124-133. [CrossRef]

61. Chowdhury, J.L.; Hu, Y.; Haltas, I.; Balta-Ozkan, N.; Matthew, G.; Varga, L. Reducing industrial energy demand in the UK: A review of energy efficiency technologies and energy saving potential in selected sectors. Renew. Sustain. Energy Rev. 2018, 94, 1153-1178. [CrossRef]

62. Gökgöz, F.; Güvercin, M.T. Energy security and renewable energy efficiency in EU. Renew. Sustain. Energy Rev. 2018, 96, 226-239. [CrossRef]

63. Amountzias, C.; Dagdeviren, H.; Patokos, T. Pricing decisions and market power in the UK electricity market: A VECM approach. Energy Policy 2017, 108, 467-473. [CrossRef]

64. Bhagwat, P.C.; Marcheselli, A.; Richstein, J.O.; Chappin, E.J.L.; De Vries, L.J. An analysis of a forward capacity market with long-term contracts. Energy Policy 2017, 111, 255-267. [CrossRef]

65. LCP Review of the T-4 2018 CM Auction. Available online: https://www.frontier-economics.com/media/ 1128/20180323_review-of-the-t-4-2018-cm-auction_frontier.pdf (accessed on 2 February 2019).

66. Capacity Market-The Design of Functional Solutions. Available online: https://docplayer.pl/30955889Rynek-mocy-projekt-rozwiazan-funkcjonalnych.html (accessed on 2 February 2019).

67. The Polish Draft Act on the Capacity Market in light of EU Law. Available online: https: / / www.documents.clientearth.org/wp-content/uploads/library/2017-03-01-the-polish-draft-acton-the-capacity-market-in-light-of-eu-law-ce-pl.pdf (accessed on 2 February 2019).

68. The Act of 8 December 2017 on the Power Market. Available online: http://dziennikustaw.gov.pl/DU/ 2018/0009 (accessed on 2 February 2019).

69. Conclusions from Prognostic Analyzes for the Energy Sector-Attachment 1 to Poland's Energy Policy Until 2040 (PEP2040)—Project of Ministry of Energy. Available online: https:/ / www.gov.pl/documents / 33372/436746/Wnioski_z_analiz_do_PEP2040_2018-11-23.pdf/1481a6a9-b87f-a545-4ad8-e1ab467175cf (accessed on 2 February 2019).

70. Demand Response Status in Member States: Mapping through Real Case Experiences. Available online: https: / /e3p.jrc.ec.europa.eu/articles / demand-response-status-member-states-mapping-throughreal-case-experiences (accessed on 22 February 2019).

(C) 2019 by the authors. Licensee MDPI, Basel, Switzerland. This article is an open access article distributed under the terms and conditions of the Creative Commons Attribution (CC BY) license (http://creativecommons.org/licenses/by/4.0/). 